\title{
Callus Induction and Plant Regeneration from Immature Embryos of Zelkova sinica Schneid.
}

\author{
Xiaoling Jin ${ }^{1}$ and Xijun Hu \\ College of Landscape Architecture, Central South University of Forestry and \\ Technology, South Shaoshan Road 498, Changsha 410004, China
}

Youping Sun

Hunan Academy of Forestry, Changsha 410004, China; and the Department of

Plant, Soil and Environmental Sciences, University of Maine, Orono, ME 04469

Donglin Zhang

College of Landscape Architecture, Central South University of Forestry and Technology, South Shaoshan Road 498, Changsha 410004, China; and the Department of Plant, Soil and Environmental Sciences, University of Maine, Orono, ME 04469

\section{Ping He}

College of Landscape Architecture, Central South University of Forestry and Technology, South Shaoshan Road 498, Changsha 410004, China

Additional index words. 6-Benzylaminopurine, callus, indole-3-butyric acid, $\alpha$-naphthaleneacetic acid, woody plant medium

\begin{abstract}
Zelkova sinica Schneid. is a popular landscape plant in China because of its wide adaptation, strong disease resistance, large crown, and beautiful fall color. Immature embryos from $Z$. sinica seeds were cultured on woody plant medium (WPM) supplemented with $4.5 \mu M$ 6-Benzylaminopurine (BA) and $5.4 \mu M \alpha$-naphthaleneacetic acid (NAA) to induce callus, and $60 \%$ of immature embryos formed callus. The cream-white, friable, nodular callus with proembryogenic structures was then cultured on WPM containing 5.4 $\mu \mathrm{M}$ NAA in combination with 9.0 or $11.2 \mu \mathrm{M}$ BA to regenerate shoots; approximately five shoots per explant were induced on $70 \%$ callus. Shoots were rooted on WPM containing 0.5 $\mu M$ indole-3-butyric acid (IBA), on which $62.3 \%$ shoots developed roots with an average of 4.2 roots per shoot at 4 weeks. The regenerated plantlets were acclimatized and transplanted into the field. This protocol could be used for mass production for field plantation, genetic improvement, and germplasm exchange of $Z$. sinica.
\end{abstract}

Zelkova sinica Schneid. is naturally distributed in the northwestern region at an altitude of 300 to $2500 \mathrm{~m}$ in China (Chen and Huang, 1999; Editing Committee of Zhongtiao Mountain Tree species, 1995). It has been introduced into Korea, Japan, and the United States (Hawley, 1971). Z. sinica is one of the most popular landscape plants in China because of its adaptability to varied environmental conditions, strong disease resistance, outstanding crown, and beautiful fall color (Jin and He, 2005). Its hard wood is widely used for making furniture because of its beautiful and durable

Received for publication 21 Nov. 2011. Accepted for publication 13 Apr. 2012.

This work was supported by the Non-profit Forestry Financial Program, Ministry of Forestry, Beijing, China (No. 200904011) and Introduction Program of International Advanced Forestry Science and Technology ("948" program), Ministry of Forestry, Beijing, China (No. 2009-4-03).

Maine Agriculture, Forestry, and Experiment Station Publication No. 3271.

${ }^{1}$ To whom reprint requests should be addressed; e-mail jx10716@hotmail.com. texture. Z. sinica has become a rare and endangered species in China as a result of overexploitation of the wild plants for commercial purposes and inefficient propagation methods (Fu and Jin, 1992). Seed propagation of $Z$. sinica is limited because seed germination was very low (10\% to $20 \%$ ) (Dou et al., 2009), and propagation of a specific cultivar is impossible because of seedling variability. Vegetative propagation of $Z$. sinica by cuttings may be subject to seasonal variations. There is an urgent need to develop an efficient protocol for the large-scale propagation of $Z$. sinica to meet the ever-increasing demand, conserve its germplasm, and genetic diversity.

Micropropagation offers a rapid means of clonal regeneration for reforestation, gardening, and germplasm conservation (Fenning and Gershenzin, 2002). Gao et al. (1996) reported that embryos, cotyledons, hypocotyls, terminal buds, and single nodes containing axillary buds of $Z$. serrata could regenerate in vitro shoots. Ito and Kondo (1995) found that BA was a good cytokinin for shoot induction from axillary buds of $Z$. serrata (Thunb.) Makino. Jin et al. (2009) reported a successful protocol of in vitro regeneration of Z. schneideriana using leaf explants. However, little information is available for plant regeneration of $Z$. sinica. The aim of this study was to develop in vitro regeneration and rooting for $Z$. sinica from immature embryos.

\section{Materials and Methods}

Plant material and explant disinfestation. Immature green seeds were collected from a 30 -year-old $Z$. sinica tree in a natural forest in the eastern Henan (China) in July 2009. Immature seeds were thoroughly rinsed for $30 \mathrm{~min}$ in running tap water, then surfacedisinfested for $10 \mathrm{~min}$ with $10 \%(\mathrm{v} / \mathrm{v}) \mathrm{com}$ mercial bleach $(5.25 \%$ sodium hypochlorite), and rinsed in distilled water five or six times. The seeds were then surface-disinfested in $75 \%(\mathrm{v} / \mathrm{v})$ ethanol for $5 \mathrm{~min}$ per rinse, then in $50 \%(\mathrm{v} / \mathrm{v})$ commercial bleach for $15 \mathrm{~min}$, and rinsed five or six times ( 5 min per rinse) with sterile distilled water. The pericarp and testa of the seeds were removed, and the immature embryos were excised as explants for callus induction.

Callus induction and shoot formation. Immature embryos were cultured on WPM (Lloyd and McCown, 1980) supplemented with 0.45, $4.5,9.0$, or $18.0 \mu \mathrm{M} 2$, 4-dichlorophenoxyacetic acid (2,4-D), BA, zeatin, 4-hydroxy-3-methyltrans-2-butenylaminopurine (ZT), or $0.54,5.4$, 10.8 , or $21.6 \mu \mathrm{M}$ NAA for callus induction. WPM without any plant growth regulator (PGR) was prepared as a control medium. Media containing $0.45,4.5$, or $9.0 \mu \mathrm{M}$ BA in combination with $4.5 \mu \mathrm{M} 2,4-\mathrm{D}$ or $5.4 \mu \mathrm{M}$ NAA were further evaluated. All media contained $20 \mathrm{~g} \cdot \mathrm{L}^{-1}$ sucrose and were solidified with $7 \mathrm{~g} \cdot \mathrm{L}^{-1}$ agar (A7921; Sigma Aldrich, St. Louis, $\mathrm{MO}$ ). The media were adjusted to $\mathrm{pH} 5.7 \mathrm{using}$ $0.1 \mathrm{~N} \mathrm{NaOH}$ or HCI before being autoclaved for $20 \mathrm{~min}$ at $121^{\circ} \mathrm{C}$. A total of $30 \mathrm{~mL}$ of the media was transferred by graduate cylinder into 250-mL glass flasks, which were covered with polypropylene plastic with paper filter discs. All cultures were maintained in a growth room at $25 \pm 2{ }^{\circ} \mathrm{C}$ with a 16-h light photoperiod $\left(50 \mu \mathrm{mol} \cdot \mathrm{m}^{-2} \cdot \mathrm{s}^{-1}\right.$ from cool white fluorescent tubes). The presence of callus was recorded after 1 month of culture. The induced callus was subcultured to fresh treatment medium every 4 weeks. The callus was divided into 2 - to 4-mm diameter pieces during transfer and subculture. At each stage of subculture, half of the callus pieces were transferred to WPM supplemented with $0,4.5,9.0$, or $13.5 \mu \mathrm{M}$ $\mathrm{BA}$ alone or $5.4 \mu \mathrm{M}$ NAA in combination with $6.7,9.0$, or $11.2 \mu \mathrm{M}$ BA for shoot induction. The presence or absence of shoots and number of shoots per explant were recorded after 6 weeks.

Rooting and acclimatization. Regenerated shoots $(\approx 2 \mathrm{~cm})$ were transferred onto a rooting medium: WPM supplemented with $0.27,0.54,2.7$, or $5.4 \mu \mathrm{M}$ NAA or 0.25 , $0.5,2.5$, or $5.0 \mu \mathrm{M}$ IBA.WPM without any auxin was prepared as a control medium. The presence or absence of roots and the number of roots per shoot were recorded after 4 weeks. Regenerated plantlets with 
well-developed roots were transplanted to small plastic pots $(9 \mathrm{~cm}$ in diameter) containing regular red soil. The roots were thoroughly washed in distilled water before transplanted. Plants were covered with plastic and maintained in a glasshouse under humidity at $\approx 90 \%, 25 \pm 2{ }^{\circ} \mathrm{C}$ temperature, over a 11 - to 12 -h photoperiod during June 2010. Two months later, plants were moved out of the glasshouse and placed in a shady area $(\approx 60 \%$ shade $)$. Two months later, all plants were then repotted in larger pots with 1 sphagnum peat : 3 red soil (by volume) and eventually planted in the field.

Experimental design and statistical analysis. A completely randomized design was used for all experiments. Each treatment was replicated three times with 15 explants per treatment per replicate. Data for the presence or absence of callus, shoots, or roots were calculated as the percentage of explants with callus, shoots, or roots, respectively. All data were analyzed using JMP ${ }^{\circledR} 9.0$ (SAS Institute, Inc., 2011). Analysis of variance (ANOVA) was performed at $P<0.05$ and Tukey's honestly significant difference test was applied for mean separations. Trend analysis for each cytokinin was also conducted.

Table 1. Callus induction from immature embryos of $Z$. sinica cultured for 4 weeks on WPM with PGRs at various concentrations.

\begin{tabular}{cccccc}
\hline \multicolumn{2}{c}{ PGRs $(\mu \mathrm{M})$} & & & \\
\hline $2,4-\mathrm{D}$ & NAA & BA & ZT & Percent explants with callus & Callus morphology \\
\hline 0 & 0 & 0 & 0 & $0.0 \pm 0.0 \mathrm{~d}^{\mathrm{z}}$ & - \\
0.45 & & & $0.0 \pm 0.0 \mathrm{~d}$ & - \\
4.5 & & & $22.2 \pm 2.2 \mathrm{bc}$ & White, soft, watery \\
9.0 & & & $28.9 \pm 2.2 \mathrm{ab}$ & White, soft, watery \\
18.0 & & & $42.2 \pm 5.9 \mathrm{a}$ & White, soft, watery \\
& 0.54 & & $11.1 \pm 2.2 \mathrm{~cd}$ & Yellow to white, soft \\
& 5.4 & & $9.0 \pm 2.1 \mathrm{f} \mathrm{cd}$ & Yellow to white, soft \\
& & & $11.1 \pm 2.2 \mathrm{~cd}$ & Yellow to white, soft \\
& & & $20.0 \pm 3.9 \mathrm{bc}$ & Yellow to white, soft \\
& & & $17.8 \pm 4.5 \mathrm{bc}$ & Cream white, friable \\
& & & $40.0 \pm 3.9 \mathrm{a}$ & Cream white, friable \\
& 0.45 & & $22.2 \pm 2.2 \mathrm{a}$ & Cream white, friable \\
& 4.5 & & $22.2 \pm 2.2 \mathrm{bc}$ & Cream white, friable \\
& 9.0 & & $9.0 \pm 2.2 \mathrm{f} \mathrm{cd}$ & White, compact \\
& 18.0 & 0.45 & $13.3 \pm 3.8 \mathrm{bcd}$ & White, compact \\
& & 4.5 & $17.8 \pm 4.5 \mathrm{bc}$ & White, compact \\
& & 9.0 & $15.6 \pm 5.9 \mathrm{bcd}$ & White, compact \\
\hline
\end{tabular}

${ }^{\mathrm{z}}$ Mean \pm SE of three replicates with 15 explants per treatment per replicate.

'Data followed by the same letters were not significantly different at $P<0.05$ according to Tukey's honestly significant difference mean separation.

$\mathrm{WPM}=$ woody plant medium; PGRs = plant growth regulators; $2,4-\mathrm{D}=2$, 4-dichlorophenoxyacetic acid; $\mathrm{NAA}=\alpha$-naphthaleneacetic acid; $\mathrm{BA}=6$-Benzylaminopurine; $\mathrm{ZT}=$ zeatin.

Table 2. Callus induction from immature embryos of $Z$. sinica cultured for 4 weeks on WPM with PGRs at various concentrations.

\begin{tabular}{lllcl}
\hline & PGRs $(\mu \mathrm{M})$ & & & \\
\hline $2,4-\mathrm{D}$ & NAA & BA & Percent explants with callus & Callus morphology \\
\hline 4.5 & & 0.45 & $31.1 \pm 5.9 \mathrm{~b}^{\mathrm{y}}$ & White, soft, watery \\
4.5 & & 4.5 & $28.9 \pm 5.9 \mathrm{~b}$ & White, soft, watery \\
4.5 & & 9.0 & $28.9 \pm 2.2 \mathrm{~b}$ & White, soft, watery \\
& 5.4 & 0.45 & $42.2 \pm 5.9 \mathrm{ab}$ & Yellow to white, friable, nodular \\
& 5.4 & 4.5 & $60.3 \pm 4.2 \mathrm{a}$ & Yellow to white, friable, nodular \\
& 5.4 & 9.0 & $33.3 \pm 3.8 \mathrm{~b}$ & Yellow to white, friable, nodular \\
\hline
\end{tabular}

${ }^{\mathrm{z}}$ Mean \pm SE of three replicates with 15 explants per treatment per replicate.

'Data followed by the same letters were not significantly different at $P<0.05$ according to Tukey's honestly significant difference mean separation.

$\mathrm{WPM}=$ woody plant medium; PGRs = plant growth regulators; 2,4-D = 2, 4-dichlorophenoxyacetic acid; $\mathrm{NAA}=\alpha$-naphthaleneacetic acid; BA $=6$-Benzylaminopurine. with 2,4-D (Tables 1 and 2), and these turned brown and died eventually when subcultured. However, yellow to creamy white, friable callus formed on explants cultured on media with BA alone or in combination with NAA (Table 1; Fig. 1A). This callus grew vigorously and began turning green and forming a nodular embryogenic structure (Table 2; Fig. 1B).

The creamy white, friable, nodular callus was cultured on WPM supplemented with $\mathrm{BA}$ alone or in combination with NAA for shoot induction. Adventitious shoots began to emerge from the callus after 4 weeks of culture (Fig. 1C). At 6-week culture, a significant difference among treatments was observed for the regeneration frequency $(P<$ $0.0001)$ and the number of shoots per callus $(P<0.0001)$ (Table 3). Approximately three shoots per explant regenerated on $47 \%$ of callus cultured on medium with $9.0 \mu \mathrm{M}$ BA. NAA at $5.4 \mu \mathrm{M}$ in combination with 9.0 or $11.2 \mu \mathrm{M}$ BA stimulated more shoot formation. Over $67 \%$ of explants formed shoots with approximately five shoots per explant induced (Fig. 1D). The ideal concentrations for in vitro culture depend on species and source of explants. Ito and Kondo (1995) reported that BA at $1.1 \mu \mathrm{M}$ was the best concentration for shoot induction of $Z$. serrata from axillary buds. Biroščlková et al. (2004) reported that $1.8 \mu \mathrm{M}$ BA was the most optimal treatment for shoot induction of $U$. glabra from dormant axillary buds. Thakur and Karnosky (2007) documented that WPM with $2.2 \mu \mathrm{M}$ BA was found to be the best medium for meristematic shoot development of Chinese elm (U. parvifolia Jacq. 'A/Ross Central Park') using newly flushed nodal segments. Jin et al. (2009) observed that 4.5 $\mu \mathrm{M}$ BA significantly enhanced shoot induction from leaf explants of $Z$. schneideriana.

Roots began to appear after culture for 1 week. The PGRs significantly affected root formation and the number of roots formed per shoot $(P<0.0001)$ in comparison with the control (no auxin) (Table 4). Two-way ANOVA showed that IBA was more effective in promoting root induction in terms of the percentage of explants with roots $(P=0.02)$. However, the percentage of explants with roots among all tested concentrations were similar $(P=0.91)$, and there was no interaction between the type of auxin and their concentration $(P=0.86)$. The ideal concentrations for promoting root initiation was not determined ( $P=0.33$ for IBA and $P=0.88$ for NAA). In addition, IBA induced more roots per shoot than NAA $(P<0.0001)$, and higher IBA concentrations linearly reduced the number of roots $(P=0.02)$. An interaction between the auxin and the concentration also occurred in terms of the number of roots per shoot $(P=$ 0.009). The highest percentage of explants with roots, $62.3 \% \pm 4.5 \%$, was recorded in the medium containing $0.5 \mu \mathrm{M}$ IBA (Table 4; Fig. 1E). An average of 4.2 roots per shoot regenerated in that medium. Shoots in the medium with NAA had a lower percentage of rooting and root numbers. Callus was observed at the base of the shoots, which inhibited the growth and elongation of roots. 


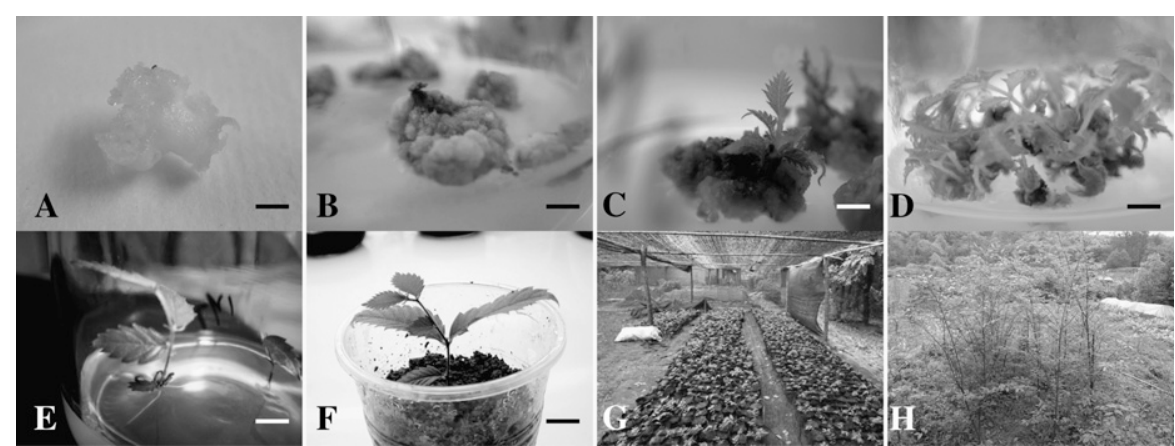

Fig. 1. Callus induction and plant regeneration from immature embryos of $Z$. sinica. (A) Callus induced on WPM containing $4.5 \mu \mathrm{MBA}$ and $5.4 \mu \mathrm{MNAA}$, scale bar $=3 \mathrm{~mm}$; $(\mathbf{B})$ green friable nodular callus formed after two subcultures on fresh treatment medium, scale bar $=2 \mathrm{~mm}$; (C) shoot regeneration from callus cultured on WPM containing 9.0 $\mu \mathrm{MBA}$ and 5.4 $\mu \mathrm{M}$ NAA, scale bar $=1 \mathrm{~mm}$; (D) multiple shoots formed when subcultured on WPM supplemented with $9.0 \mu \mathrm{M}$ BA and $5.4 \mu \mathrm{M}$ NAA, scale bar $=2 \mathrm{~mm}$; $(\mathbf{E})$ shoots rooted on WPM containing $0.5 \mu \mathrm{M}$ IBA after 2 weeks, scale bar $=3 \mathrm{~mm} ;(\mathbf{F})$ plantlets acclimatized in a plastic cup containing red soil in a glasshouse for 4 weeks, scale bar $=1 \mathrm{~cm} ;(\mathbf{G})$ plants acclimatized in a shady area $(\approx 60 \%$ shade $) ;(\mathbf{H})$ plants established in the field $(\approx 2$ years $)$. WPM = woody plant medium; $\mathrm{BA}=6$-Benzylaminopurine; NAA $=\alpha$-naphthaleneacetic acid; IBA $=$ indole-3-butyric acid.

Table 3. Adventitious shoots of $Z$. sinica regenerated from callus cultured for 6 weeks on WPM with BA and NAA at various concentrations.

\begin{tabular}{rccc}
\hline \multicolumn{2}{c}{ PGRs $(\mu \mathrm{M})$} & & \\
\hline BA & NAA & Percent explants with shoot & \\
\hline 0 & 0 & $0.0 \pm 0.0 \mathrm{c}^{\mathrm{y}}$ & No. of shoots per explant \\
4.5 & 0 & $28.9 \pm 5.9 \mathrm{~b}$ & $0.0 \pm 0.0 \mathrm{~d}$ \\
9.0 & 0 & $46.7 \pm 3.8 \mathrm{~b}$ & $1.4 \pm 0.2 \mathrm{c}$ \\
13.5 & 0 & $28.9 \pm 2.2 \mathrm{~b}$ & $2.7 \pm 0.1 \mathrm{~b}$ \\
6.7 & 5.4 & $33.3 \pm 3.8 \mathrm{~b}$ & $1.3 \pm 0.3 \mathrm{c}$ \\
9.0 & 5.4 & $71.1 \pm 4.4 \mathrm{a}$ & $1.9 \pm 0.4 \mathrm{bc}$ \\
11.2 & 5.4 & $66.7 \pm 3.8 \mathrm{a}$ & $4.6 \pm 0.2 \mathrm{a}$ \\
\hline
\end{tabular}

${ }^{\mathrm{z}}$ Mean \pm SE of three replicates with 15 explants per treatment per replicate.

${ }^{y}$ Data followed by the same letters within column were not significantly different at $P<0.05$ according to Tukey's honestly significant difference separation.

$\mathrm{WPM}=$ woody plant medium; $\mathrm{BA}=6$-Benzylaminopurine; $\mathrm{NAA}=\alpha$-naphthaleneacetic acid; PGRs $=$ plant growth regulators.

Table 4. In vitro root induction of $Z$. sinica cultured for 4 weeks on WPM supplemented with IBA and NAA at various concentrations.

\begin{tabular}{lccc}
\hline IBA $(\mu \mathrm{M})$ & NAA $(\mu \mathrm{M})$ & Percent explants with roots $^{\mathbf{z}}$ & No. of roots per shoot \\
\hline 0 & 0 & $0.0 \pm 0.0 \mathrm{~d}^{\mathrm{y}}$ & $0.0 \pm 0.0 \mathrm{~d}$ \\
0 & 0.27 & $22.2 \pm 4.5 \mathrm{~cd}$ & $1.3 \pm 0.1 \mathrm{c}$ \\
0 & 0.54 & $42.2 \pm 4.5 \mathrm{abc}$ & $1.5 \pm 0.2 \mathrm{c}$ \\
0 & 2.7 & $33.4 \pm 6.7 \mathrm{bc}$ & $1.6 \pm 0.2 \mathrm{c}$ \\
0 & 5.4 & $33.3 \pm 3.8 \mathrm{bc}$ & $1.5 \pm 0.2 \mathrm{dc}$ \\
0.25 & 0 & $28.9 \pm 5.9 \mathrm{c}$ & $2.9 \pm 0.3 \mathrm{~b}$ \\
0.5 & 0 & $62.3 \pm 4.5 \mathrm{a}$ & $4.2 \pm 0.2 \mathrm{a}$ \\
2.5 & 0 & $55.6 \pm 5.9 \mathrm{ab}$ & $3.1 \pm 0.3 \mathrm{~b}$ \\
5.0 & 0 & $42.3 \pm 4.5 \mathrm{abc}$ & $2.2 \pm 0.1 \mathrm{bc}$ \\
\hline
\end{tabular}

${ }^{\mathrm{z}}$ Mean \pm SE of three replicates with 15 explants per treatment per replicate.

${ }^{\text {y }}$ Data followed by the same letters within column were not significantly different at $P<0.05$ according to Tukey's honestly significant difference separation.

$\mathrm{WPM}=$ woody plant medium; IBA $=$ indole-3-butyric acid; NAA $=\alpha$-naphthaleneacetic acid.

After transplanting, this type of plantlet finds it difficult to survive (Sun et al., 2010). The current results were in agreement with previous reports, which recorded IBA as the best rooting auxin for Drymaria cordata (L.) Willd. ex Schult. (Ghimire et al., 2010), Dorem ammoniacum D. (Irvani et al., 2010), Stereospermum personatum (Hassk.) Chatterjee (Susmita et al., 2009), and $U$. glabra (Birošćlková et al., 2004). However, Thakur and Karnosky (2007) observed that WPM with $5.4 \mu \mathrm{M}$ NAA was best for rhizogenesis of regenerants and microcuttings of Chinese elm.
Regenerated plantlets with well-developed roots were transplanted in plastic pots and acclimatized in a greenhouse (Fig. 1F). The survival rates were $90 \% \pm 12.1 \%$. Two months later, plants were moved out of the glasshouse and placed in a shady area $(\approx 60 \%$ shade; Fig. $1 \mathrm{G})$. The surviving plants were 8 to $10 \mathrm{~cm}$ tall after acclimatization. All live plants were then planted in the field, and $80 \% \pm 8.6 \%$ of plants survived 17 months later. They were 197.2 \pm $22.5 \mathrm{~cm}$ tall with a base diameter of $1.89 \pm$ $0.54 \mathrm{~cm}$ (Fig. 1H).

In summary, immature embryos were cultured on WPM containing 5.4 $\mu \mathrm{M}$ NAA and
4.5 $\mu \mathrm{M}$ BA to induce callus. The creamy white, friable, nodular callus were then cultured on a WPM containing 5.4 $\mu \mathrm{M}$ NAA in combination with 9.0 or $11.2 \mu \mathrm{M}$ BA to regenerate shoots. Approximately five shoots per explant were induced. These shoots were rooted in WPM containing $0.5 \mu \mathrm{M}$ IBA. The regenerated plantlets were acclimatized and successfully transplanted into the field.

\section{Literature Cited}

Biroščĺková, M., K. Spišáková, Š. Lipták, V. Pichler, and J. Durkovič. 2004. Micropropagation of mature wych elm (Ulmus glabra Huds.). Plant Cell Rpt. 22:640-644.

Chen, H.Y. and C.G. Huang. 1999. Ulmaceae, p. 385. In: Editorial Committee of Chinese Floral (ed.). Flora Republicae Popularis Sinicae. Vol. 22. Science Press, Beijing, China.

Dou, Q.Q., X.J. Jiao, M. Zhang, K.Y. He, and L.B. Huang. 2009. Physiological response of $Z$. schneideriana seedlings in the soil under $\mathrm{NaCl}$ stress. Acta Botanica Boreali-Occidentalia Sinica 29:2063-2069.

Editing Committee of Zhongtiao Mountain Tree species. 1995. Zhongtiao Mountain tree species. Forestry Press, Beijing, China.

Fenning, T.M. and J. Gershenzin. 2002. Where will the wood come from? Plantation forests and the role of biotechnology. Trends Biotechnol. 20:291-296.

Fu, L.G. and J.M. Jin. 1992. Plants red book of China-Rare and endangered plants. Vol. I. Science Press, Beijing, China.

Gao, Y.Y., Y.N. Wang, and J.H. Jiang. 1996. Tissue culture of $Z$. serrata. Quarterly J. Chinese For. 29:171-186.

Ghimire, B.K., E.S. Seong, E.J. Goh, N.Y. Kim, W.H. Kang, E.H. Kim, C.Y. Yu, and I.M. Chung. 2010. High-frequency direct shoot regeneration from Drymaria cordata Willd. leaves. Plant Cell Tissue Organ Cult. 100:209-217.

Hawley, W.O. 1971. Zelkova sinica. Amer. Hort. Mag. 50:188.

Irvani, N., M. Solouki, and M. Omidi. 2010. Callus induction and plant regeneration in Dorem ammoniacum D., an endangered medicinal plant. Plant Cell Tissue Organ Cult. 100:293-299.

Ito, R. and T. Kondo. 1995. Tissue culture of axillary buds and seedlings of Zelkova serrata. Bulletin of the National Forest Tree Breeding Center 13:27-32

Jin, X.L. and P. He. 2005. Biological characteristics in Zelkova. Nonwood For. Res. 23:45-47.

Jin, X.L., R.Q. Zhang, D.L. Zhang, P. He, and F.X. Cao. 2009. In vitro plant regeneration of an endangered Zelkova schneideriana Hand.-Mazz. from leaf explants. J. Hort. Sci. Biotechnol. $84: 415-420$.

Lloyd, G. and B. McCown. 1980. Commercial feasible micropropagation of mountain laurel $\mathrm{Kal}$ mia latifolia by use of shoot tip culture. Comb. Proc. Intl. Plant Propagators Soc. 30:421-427.

SAS Institute Inc. 2011. JMP, Version 7. SAS Institute Inc., Cary, NC.

Sun, Y.P., D.L. Zhang, and J. Smagula. 2010. Micropropagation of Ilex glabra (L.) A. Gray. HortScience 45:805-808.

Susmita, S., S.K. Shukla, and S.K. Mishra. 2009. In vitro plant regeneration from seedling explants of Stereospermum personatum D.C.: A medicinal tree. Trees Structure and Function 23:409-413.

Thakur, R.C. and D.F. Karnosky. 2007. Micropropagation and germplasm conservation of Central Park Splendor Chinese elm (Ulmus parvifolia Jacq. 'A/Ross Central Park') trees. Plant Cell Rpt. 26:1171-1177. 